\title{
A apreciação do radiojornalismo praticado em Goiás. Pesquisa realizada com motoristas de táxi
}

\author{
Lisa França *
}

\begin{abstract}
Resumo
Esta contribuição é um relato da pesquisa realiza da com 294 motoristas de táxi, ouvintes de rádio, nas cidades de Goiânia e Anápolis, em janeiro e fevereiro de 2002. A intenção era avaliar, por meio da recepção, o jornalismo praticado pelas principais emissoras de rádio no estado e conhecer a apreciação dessa audiência. A pesquisa foi concebida como atividade acadêmica dos alunos do segundo ano de Jornalismo da FACOMB-UFG, que cursavam, na época, a disciplina obrigatória Radiojornalismo.

Palavras-chave: pesquisa, motoristas de táxi, audiência de rádio.
\end{abstract}

Esta pesquisa nasceu de uma preocupação pedagógica da disciplina Radiojornalismo, do curso de Jornalismo da Universidade Federal de Goiás. A intenção era conhecer melhor o jornalismo praticado pelas rádios no estado e sua interação com a recepção. Sentimos necessidade de realizar o estudo principalmente porque o radiojornalismo não costuma motivar os estudantes do curso de Jornalismo, que chegam ao segundo ano sonhando com mídias de maior prestígio, dentre elas, especialmente, a televisão e c jornal diário.

Por outro lado, o rádio ainda é considerado, pelos pesquisadores da Comunicação Social, como um instrumento poderoso de informação e mobilização social. Muitas de suas estrelas conseguem passar

* Doutora e Mestre em Comunicação Social pela Universidade Autônoma de Barcelona, jornalista e professora da Faculdade de Comunicação Social e Biblioteconomia da Universidade Federal de Goiás.

Comun. Inf., v. 4, n. 1/2, p.159-167, jan./dez. 2001 
para o mundo político ancorados apenas no trabalho profissional como locutor ou comunicador. Um dos casos mais notáveis de Goiás é o do deputado federal Sandes Júnior, produtor e apresentador de programa radiofônico, eleito em 2002 como um dos candidatos mais votados, com 126.777 votos. O locutor/político já havia sido eleito outras duas vezes deputado estadual, ajudado pela popularidade de seu programa radiofônico.

Para delimitar o universo da investigação, fundamentamos-nos em relatos de pesquisas recentes de mídia, que apontam duas tendências atuais no cenário de consumo de mídia eletrônica: o rádio como um produto de consumo mediático ligado ao automóvel e os taxistas como grandes ouvintes de rádio (SCANNEL, 2001). Baseados nesses dois fatos atestados decidimos por realizar a pesquisa exclusivamente com motoristas de táxi, porque, além de reduzir a investigação a um único segmento social que nos permitiria considerações mais exatas na análise de recepção, nos concentraríamos em um universo quase confirmado de ouvintes de noticiário radiofônico.

Definimos em sala de aula um questionário sociomediático com perguntas fechadas e também abertas para permitir uma análise qualitativa dessa recepção. As perguntas de cunho sociológico visavam conhecer melhor essa audiência, identificar seu perfil social e cultural, mesmo para poder, com o cruzamento dos dados, compreender como se dava a recepção e sua avaliação crítica sobre o radiojornalismo praticado no estado.

O objetivo específico era avaliar o radiojornalismo local por meio da recepção de motoristas de táxi de Goiânia e Anápolis, conhecer a dimensão dessa recepção e a apreciação do radiojornalismo atual praticado pelas emissoras locais. Incluimos também, por interesse específico da turma, perguntas sobre a preferência pelo gênero na locução e tipo de notícia.

Cada aluno se responsabilizou por aplicar o questionário a 10 taxistas. No total deveríamos ter 380 questionários aplicados, mas acabamos optando por considerar 294, que obedeceram ao rigor de checagem para análise. Consideramos que o número absoluto de 294 taxistas era adequado e, inclusive, representativo do universo que queríamos analisar. Neste estudo de caso conseguimos ouvir quase $25 \%$ da categoria nas cidades de Goiânia e Anápolis, priorizando ainda a vocação pedagógica da pesquisa.

Comun. Inf., v. 4, n. 1/2, p.159-167, jan./dez. 2001 


\section{Antecedentes da pesquisa de audiência}

Os primeiros sinais de que a audiência não é homogênea e que por isso deve ser constantemente avaliada por quem faz comunicação de massa começaram com as pesquisas da psicologia da percepção e ganharam força com os estudos da linguagem de Mikhail Bakhtin, que em sua obra de 1929, Marxismo e filosofia da linguagem, defende a importância de se considerar as expressões concretas dos indivíduo' em contextos sociais particulares. Também o pensador e lingüista americano Noam Chomsky, no seu intento de estudar a colaboração da linguagem sobre o conhecimento humano e suas relações com os problemas clássicos da filosofia do entendimento, colaborou para a valorização do conceito de receptor ativo.

Os pesquisadores franceses Armand e Michéle Mattelart chamam a atenção para a necessidade de pesquisas que identifiquem um consumidor que é soberano nas suas eleições, em um mercado de comunicações considerado livre nos países democráticos (Mattelart e Mattelart, 1997). As teorias dos usos e gratificações também aprofundaram, nos anos 80, a noção de leitura negociada. Isto é, a de que os sentidos e os efeitos dos conteúdos da comunicação nascem da interação dos textos e das funções assumidas pela audiência.

Mas foi a partir dos anos 80 , especialmente com a colaboração dos estudos culturais ingleses (Hall, Morley, Williams, Walkerdine, dentre outros) e dos estudos de audiência na América Latina (Barbero, Canclini, Orozco, Jacks, dentre outros) que as pesquisas começaram a contestar a hegemonia dos meios na produção das culturas e passaram a apontar para uma ênfase na diferença e nas variações da recepção.

Os meios de comunicação e sua programação dentro desse contexto passaram a ser estudados como representação cultural e também como vínculo social. Embora essa representação e esse vínculo sejam mediatizados, conforme defende Thompson (1998), também trazem consigo a ideologia da produção, o que tem sido objeto de preocupação dos estudos de recepção.

Hoje trabalhamos também com um conceito que vai além de Meios de Comunicação de Massa, porque as mídias se firmam no século XXI com audiências fragmentadas e formadas de grupos socialmente diversos, que se agrupam dentro de uma hierarquia de diferenciação social, o que permite a transferência cultural.

Comun. Inf., v. 4, n. 1/2, p.159-167, jan./dez. 2001 


\section{2}

Dentro desse cenário plural, interessava-nos conhecer as preferências da recepção, os pontos em comuns e o que é valorizado, principalmente nos programas essencialmente informativos, como os noticiários. Por isso, trabalhamos com perguntas específicas sobre o tipo de notícias que a audiência busca, de quais notícias sente falta e também uma apreciação crítica sobre a forma como esse noticiário é apresentado.

\section{Os motoristas de táxi como audiência específica}

Os motoristas de táxi, no Brasil urbano, como também em outras grandes cidades ocidentais, são considerados um termômetro dos anseios da sociedade, por serem uma categoria especialmente informada, pelo contato pessoal com os mais diversos tipos de passageiros, por sua mobilidade urbana e, nas últimas décadas, pelo hábito de ouvir rádio no automóvel.

Muitos políticos procuram atender reivindicações específicas da categoria, mesmo numericamente representando um eleitorado pequeno, principalmente porque acreditam no papel dessa classe como formadora de opinião de suas famílias, em seu contexto social e dentro de um segmento próprio classista. Na maioria das vezes, trata-se de eleitores masculinos, casados e com nível cultural médio. Na nossa pesquisa, 149 taxistas, 50,68\% do total, estão na faixa etária dos 41 aos 60 anos, $43,20 \%$ têm entre 21 e 40 anos, 4,76\% (14 taxistas) têm mais de 60 anos e $1,36 \%$ (4 taxistas), menos de 20 anos.

Cruzando esses dados com os de escolaridade pudemos concluir que o acesso à escola vem se modificando. Dos taxistas acima de 60 anos, a maioria, $51 \%$, parou de estudar no ensino primário e, destes, só $28,19 \%$ chegaram a concluir a escola primária, enquanto que na faixa dos 21 aos 40 anos, 37\% (47 motoristas) concluíram o secundário e $29,14 \%$ têm o secundário ou ensino médio incompleto. Registramos ainda que entre os mais jovens, $4,72 \%$ começaram um curso superior.

O grau de escolaridade também agrupa os entrevistados na preferência pelas rádios e pelo tipo de informação que procuram. Os inotoristas mais jovens citaram a Rádio Interativa como a preferida, seguida da Serra Dourada FM. Essas rảdios priorizam o público jovem, apresentam mais música pop e o noticiário é menos tradicional, com formato e linguagem modernos.

Comun. Inf., v. 4, n. 1/2, p.159-167, jan./dez. 2001 
Dos motoristas que preferem a Rádio K, emissora de maior audiência no total da pesquisa, 12 deixaram de concluir o curso primário ou ensino fundamental, 20 têm o curso primário completo e 18, o curso secundário ou médio incompleto.

O grau de escolaridade e a idade também definem hábitos da recepção dos motoristas de táxi pesquisados. Entre os de faixa etária mais alta e, conseqüentemente, escolaridade mais baixa, há uma preferência pelas notícias com comentários. Entre esse grupo, o noticiário favorito é o da Rádio K, que se notabiliza por dar as notícias com comentários.

Temos de considerar também que o hábito de ouvir notícias seria uma conseqüência de estar sintonizado nessas emissoras, que divulgam as notas jornalísticas e informativas periodicamente, entre os blocos musicais. Nos outros grupos acima de 40 anos, a preferência foi pela Rádio K, especializada em esportes e na cobertura política, e pela Rádio Terra FM, especializada em música sertaneja. O noticiário preferido também foi o apresentado pela Rádio K, que oferece as notícias com comentários dos locutores. Em segundo lugar, a preferência pelo noticiário da Rádio Terra e em terceiro lugar, pelo programa jornalístico da CBN Anhanguera.

\section{As rádios e a confiança nos noticiários}

A Rádio $\mathrm{K}$ foi citada como a favorita pelos taxistas, principalmente por causa das notícias sobre futebol (20,48\% dos motoristas ouvintes buscam nas rádios esse tipo de notícia) e "por inspirar mais confiança" -18,07 (a rádio faz oposição sistemática ao governo do estado, do PSDB). Já 25\% dos ouvintes da Rádio Terra justificaram a preferência principalmente por causa do tipo de programação musical; $17,30 \%$, por causa da informação e $17,30 \%$, por causa de melhor sintonização. Para os que escutam preferencialmente a CBN, a opção se dá por causa da quantidade de notícias $(24,48 \%)$, pela abrangência das notícias $(20,40 \%)$ e por um jornalismo mais completo $(12,94 \%)$.

Com relação ao grau de confiança dos noticiários, $44,21 \%$ disseram confiar nas notícias transmitidas, $41,49 \%$, confiaram às vezes $\mathrm{e}$ $6,46 \%$ disseram não confiar nos noticiários apresentados. Entre os entrevistados que escutam a Rádio K, 50,6\% confiam nas notícias divulgadas, $43,37 \%$ não confiam totalmente e $3,61 \%$ não confiam nunca. Entre os que escutam a Rádio Terra, $51,92 \%$ não confiam totalmente

Comun. Inf., v. 4, n. 1/2, p.159-167, jan./dez. 2001 


\section{4}

no que é divulgado, $32,69 \%$ confiam e $5,76 \%$ não confiam. Com relação aos que escutam a CBN, 59,18\% não confiam totalmente nas notícias divulgadas, $34,69 \%$ confiam totalmente e $6,12 \%$ não confiam nunca.

Interessante notar que entre os ouvintes das rádios Terra e $\mathrm{CBN}$, a grande maioria não confia plenamente no que é noticiado, lembrando que a Rádio Terra tem $32,69 \%$ dos ouvintes dizendo que confiam e a CBN, $34,69 \%$ com esta opinião. No entanto, esses números crescem bastante quando se trata dos ouvintes da Rádio K: 50,6\% dos entrevistados que escutam esta emissora disseram que confiam nas notícias divulgadas.

Várias explicações podem ser dadas para a confiança no noticiário da Rádio K, como a oposição sistemática ao governo do estado, o tipo de jornalismo praticado, com comentários e análises políticas, bem como a popularidade do locutor protagonista, que se firmou como comentarista esportivo na cidade.

\section{Notícias favoritas}

No que diz respeito ao tipo de notícias, os ouvintes da Rádio $\mathrm{K}$ preferem em primeiro lugar as informações sobre esporte (36,14\%); em segundo lugar, informações sobre política $(21,68 \%)$, e em terceiro, sobre economia (10,84\%). Entre os ouvintes da Rádio Terra, 19,23\% não têm preferência com relação ao tipo de notícia, 15,38\% preferem esporte; $15,38 \%$, preferem notícias sobre a cidade em geral; 7,69\%, informações sobre a política e $5,76 \%$, sobre a economia. Já os ouvintes da Rádio CBN preferem, em primeiro lugar, notícias sobre política $(16,32 \%)$. As notícias sobre economia, esporte e cidades aparecem em segundo lugar $(14,28 \%$ cada) e em terceiro lugar, notícias sobre o universo policial $(2,04 \%)$, sendo que $14,28 \%$ dos taxistas disseram não ter qualquer preferência sobre tipos de notícia.

Com relação ao tipo de notícia, no universo global dos taxistas ouvintes de todas as rádios, $23,12 \%$ disseram preferir as notícias sobre esportes, $17,34 \%$ preferem as notícias sobre a política, $11,56 \%$ preferem as notícias sobre economia e apareceu ainda $2,72 \%$ de preferência para as notícias sobre cultura e 2,38\% tanto para notícias nacionais como internacionais.

O fato de a maioria dos taxistas ouvidos não ter preferência por nenhum tipo de notícia talvez possa ser explicado pelas programações

Comun. Inf., v. 4, n. 1/2, p.159-167, jan./dez. 2001 
apresentadas pelas emissoras listadas como favoritas, que, no caso, são essencialmente musicais. Chama atenção também a preferência de boa parte dos entrevistados por notícias de economia.

\section{Preferência por gênero de locução}

Quanto ao tipo se locução, 25,85\% dos 294 entrevistados disseram que preferem a locução masculina, 13,94\% preferem a feminina e a grande maioria, $53,74 \%$, não tem nenhuma preferência.

\section{Agradecimentos}

Aos alunos do curso de Jornalismo que participaram da pesquisa, especialmente à aluna Edyr Faria, responsável pela confecção das tabelas no programa Access, e aos alunos Jackeline Rodrigues de Moraes, Juliana Alves Ferreira Porados, Kharen Stecca Steindorff, Lucimeire Santos, Patrícia da Veiga Borges e Rafael Ortega Inocêncio, pela excelência das suas análises.

\section{Abstract}

This contribution presents a research developed with 294 taxi-drivers in the cities of Goiânia and Anápolis in the year of 2001. They were questioned about their habits of radio listening, and their appreciation of the journalism practiced by those radios. They also informed about their belief on the news practiced, their preference for types of news and gender locution.

Keywords: research, taxi drivers, radio listening.

\section{Referências}

BAKHTIN, M. Marxismo y filosofía del linguaje. México: Siglo 21, 1965. CHOMSKY, N. El lenguaje y el entendimiento. Barcelona: Planeta Agustin, 1992.

GARCÍA CANCLINI, N. Cultura y comunicación: entre lo global y lo local. Argentina. Ediciones de Periodismo y Comunicación, Universidad Nacional de La Plata, 1997.

GARCÍA CANCLINI, N. Consumidores e cidadãos. Rio de Janeiro: Ed. UFRJ, 1995.

GARCÍA CANCLINI, N. Culturas Hibridas. México: Grijalbo, 1990.

HALL, S.; DUGAY, P. Questions of Cultural Identity. Londres: Sage, 1996.

Comun. Inf., v. 4, n. 1/2, p.159-167, jan./dez. 2001 


\section{6}

HALL, S. Encoding/decoding in television discourse. Londres: Hutchinson, 1981.

JACKS, N. Querência - Cultura Regional como Mediação Simbólica, um estudo de recepção. Porto Alegre: Universidade Federal do Rio Grande do Sul, 1999.

MATTELART, A.; MATTELART, M. Historia de las teorías de la comunicación. Barcelona: Paidós, 1997.

MATTELART, A.; MATTELART, M. Pensar sobre los medios: comunicación y crítica social. Madrid: Fundesco, 1987.

MARTIN BARBERO, J. De los Medios a las Mediaciones. Barcelona: Editorial Gustavo Gili, 1987.

MARTIN BARBERO, J. De los Medios a las Prácticas. In: . "La comunicación desde las práticas sociales: reflexiones en torno a su investigación”. México: Universidad ÍberoAmericana, 1990.

MORLEY, D. Estudios Culturales y comunucación: análisis, producción y consumo cultural de las políticas de identidad y el posmodernismo. Barcelona: Paidós, 1998.

MORLEY, D. The Nationwide Audiennce: structure and decoding. Londres: British Film Institute, 1980.

OROZCO, G. Re cepción televisa. Tres aproximaciones y una razón para su estudio. México: Universidad Iberoamericana, 1991.

SCANNEL, P. Radio, Televisión \& Modern Life. A Phenomenological Approach. Oxford: Blackwell Publishers Inc., 2001.

WALKERDINE,V. Estudios Culturales y comunicación - análisis, producción y consumo cultural de las políticas de identidad y el posmodernismo. Barcelona: Paidós, 1998.

WILLIAMS, R. Sociología de la cultura. Barcelona: Paidós, 1994.

\section{ANEXO}

\section{1- Questionário}

1 - Você gostaria de participar de uma pesquisa sobre rádio? (eliminatória)

2 - Você escuta notícias pelo rádio? Sim Não (eliminatória)

3 - Você costuma ouvir o noticiário todos os dias?

4 - Em que horário?

5 - Você escuta o noticiário de qual emissora?

6 - Por que você prefere este noticiário?

7 - Você confia nas notícias que escuta pelo rádio?

Comun. Inf., v. 4, n. 1/2, p.159-167, jan./dez. 2001 
8 - Ouvindo notícias pelo rádio você tem informações suficientes ou sente necessidade de ler jornais e/ou assistir televisão?

9 - Como você prefere as notícias pelo rádio, com comentários dos locutores ou sem comentários?

10 - Que tipo de locução você prefere, masculina ou feminina, por que?

11 - Qual o tipo de notícia que você gostaria de ouvir mais?

12 - Qual o seu nome completo?

13 - Qual a sua idade?

14 - Você tem:

- primário incompleto

- secundário incompleto

primário completo

- superior incompleto secundário completo superior completo

15 - Você é proprietário do carro?

Comun. Inf., v. 4, n. 1/2, p.159-167, jan./dez. 2001 